\title{
Impacts of a railway tunnel on the streams baseflow verified by means of numerical modelling
}

\section{Impatti di un tunnel ferroviario sul deflusso di base di torrenti verificato attraverso la modellazione numerica}

\author{
Leonardo Piccinini, Valentina Vincenzi
}

Riassunto: La linea ferroviaria ad Alta Velocità Bologna-Firenze (Italia) si sviluppa prevalentemente in sotterraneo attraverso l'Appennino Tosco-Emiliano e le gallerie drenanti hanno impattato gravemente le risorse idriche superficiali e sotterranee.

La sopra menzionata linea ferroviaria, tra l'anno 1996 e il 2005 venne realizzata con l'escavazione di 9 tunnel attraverso l'Appennino Tosco-Emiliano, per una lunghezza totale di $73 \mathrm{~km}$. Il disegno e il progetto di costruzione sono visibili nel lavoro di Lunardi del 1998 .

I principali problemi riguardanti il drenaggio si sono verificati in prossimità dello spartiacque topografico, dove la galleria attraversa torbiditi silicoclatiche della Formazione Marnoso Arenacea (FMA) una unità che viene considerata prevalentemente un nonacquifero. Nel settore Toscano della linea, a causa di importanti fenomeni di inrush nella galleria, furono necessari cambiamenti e adattamenti del progetto iniziale. A parte le procedure di gestione del rischio durante la perforazione, furono necessarie modifiche al tracciato delle gallerie e la progettazione di nuovi sistemi di rivestimento. Tutto ciò con un aggravio nei costi e nella durata dei lavori.

Keywords: numerical modelling, MODFLOW, tunnel drainage,
fractured aquifer, Tuscan-Emilian Apennine.

Parole chiave: modellazione numerica, MODFLOW, galleria drenante, acquifero fratturato, Appennino Tosco-Emiliano.

\section{Leonardo PICCININI 奉=" \\ Università degli Studi di Padova, Dipartimento di Geoscienze via G. Gradenigo 6, 35131 Padova (Italia) \\ leonardo.piccinini@unipd.it}

\section{Valentina VINCENZI}

Studio Geologico Vincenzi Valentina

via Nives Gessi 3, 44122, Ferrara (Italia)

info@idrogeologiavincenzi.it

Publication Note - This paper has been published previously (DOI: 10.4409/Am-020-10-0016), in the international journal "AQUAmundi". AQUAmundi closed in 2015 and published papers officially disappeared, being available only in secondary, personal or organizations' repositories. However, the contents of this paper are still considered of interest for readers, who suggested that Acque Sotterranee - Italian Journal of Groundwater reprint it, so here it is republished in its original form, with minor updates limited to references and data, provided in footnotes.

Received: 7 October 2010 / Accepted: 18 November 2010

Ripubblicato online/Republished online: 30 March 2021

This is an open access article under the CC BY-NC-ND license: http://creativecommons.org/licenses/by-nc-nd/4.0/

(c) Associazione Acque Sotterranee 2021
Per quanto riguarda la tutela ambientale fu istituito un programma di monitoraggio di dettaglio delle acque superficiali e sotterranee che ebbe inizio nel 1994 e ancora continua, permettendo di registrare l'impatto degli scavi su 60 sorgenti (usate per l'approvvigionamento idrico pubblico e privato) e 30 pozzi.

Tutto ciò ha permesso di evidenziare le interferenze delle gallerie sulla falda in più di 8 bacini idrografici con effetti sulla tavola d'acqua fino ad una distanza di $4 \mathrm{~km}$ dal tracciato delle gallerie. La Galleria Firenzuola, lunga $15 \mathrm{~km}$, attraversa torbiditi silicoclatiche; durante gli scavi ha intercettato venute d'acqua nelle zone di faglia e di fratturazione e il drenaggio è ancora in corso. La tavola d'acqua è scesa sotto il livello delle vallate e i torrenti che prima erano drenanti si sono trasformati in disperdenti o si sono prosciugati, come è successo a molte sorgenti. Misure idrogeologiche e due multi-tracciamenti hanno dimostrato e caratterizzato le connessioni torrenti-galleria e i processi di impatto.

Nell'ambito della progettazione di opere di mitigazione degli impatti sul deflusso dei torrenti, si è applicata la modellazione numerica tridimensionale con MODFLOW (approccio EPM) per la stima dei deflussi artificiali minimi da garantire a monte dei tratti impattati per il mantenimento della continuità di flusso sulle aste torrentizie durante la recessione estiva.

L'implementazione dei due modelli presentati è basata sui dati di monitoraggio idrogeologico e sui risultati dei profili di portata e dei test di tracciamento. Per i due torrenti maggiormente impattati sono state stimate le portate massime sottratte dalla galleria al deflusso di base dei torrenti attraverso le strutture geologiche di connessione.

Abstract: : The high-speed railway line between Bologna and Florence (Italy) is mostly developed underground through the Tuscan-Emilian Apennine, and the tunnels severely impacted groundwater and surface water. The 15-km-long Firenzuola tunnel crosses siliciclastic turbidites: during drilling, water inrushes occurred at fault and fracture zones, and the tunnel continues to drain the aquifer. The water table dropped below the level of the valleys, and gaining streams transformed into losing streams or ran completely dry, as did many springs. Hydrological observations and two multitracer tests have previously characterized the stream-tunnel connections and the impact processes.

In the framework of planning mitigation strategies to minimize impacts on stream baseflow, three-dimensional numerical modelling with MODFLOW (the EPM approach) is applied to evaluate the artificial minimum flow needed to maintain flow continuity along the stream during the recession phase. The establishment of the two presented models is based on bydrogeological monitoring data and the results of flow measurements and tracer tests. Maximum flow rates subtracted from stream baseflow by the tunnel along the connection structures are calculated for two streams with major impacts. 


\section{Introduction}

The drilling of several tunnels for the Bologna-Florence high-speed railway line (Italy) induced the drainage of large groundwater volumes. This effect was not anticipated during the preconstruction phase and design project planning phase, causing substantial problems both for construction and in the work environment.

Between 1996 and 2005, the abovementioned railway line was completed with the drilling of 9 tunnels across the Tuscan-Emilian Apennine chain over a total length of $73 \mathrm{~km}$ (Vallino Costassa et al. 1997; Lunardi 1998). The design and construction of the tunnels is available in Lunardi (2008). Major drainage problems occurred near the main topographic divide, where the tunnels cross the siliciclastic turbidites of the Marnoso Arenacea Formation (FMA) (Ricci Lucchi 1975, 1978, 1980, 1981; Mutti 1985; Mutti and Normark 1987; Mutti 1992; Martelli 2004), a geological unit previously considered a nonaquifer.

In the Tuscan sector of the line, huge inrush phenomena required project changes and adaptations due to groundwater in tunnels; aside from risk management procedures during the drilling phase, new construction operations were needed, e.g., new planning of lining systems, rock mass linings and changes in the planned route of the tunnels. All these changes increased the cost and duration of the works. Concerning environmental issues, a detailed monitoring program on superficial water and groundwater started in 1994 and is still ongoing (Agnelli et al. 1999), allowing the impact on 60 springs (for private use and public water supply) and 30 wells to be recorded; furthermore, it allowed the interferences with stream baseflow in more than 8 watersheds to be documented (Canuti et al. 2009), with effects on the surface that propagated to a distance of $4 \mathrm{~km}$ from the tunnel line. This large database (Canuti et al. 2009) allowed a conceptual model of groundwater flow systems in turbidites to be defined (Gargini et al. 2006, 2008) and confirmed by further studies (Vincenzi et al. 2009).

In this paper, two case studies are presented, in which numerical modelling is applied to simulate Firenzuola tunnel drainage impacts on the streams of two watersheds. The modelling approach is one of equivalent porous medium (EPM) (Pankow et al. 1986; Gburek et al. 1999; Rayne et al. 2001; Scanlon et al. 2003; Paradis et al. 2007) through the finite difference code MODFLOW 2000 (Harbaugh et al. 2000).

\section{Geological setting}

The Firenzuola tunnel is $15,060 \mathrm{~m}$ long and crosses the main topographic divide between the Santerno River on the northern side and the Arno River on the southern side (Fig. 1). Drilling works started in 1997 with 4 shafts (a total length of $3,519 \mathrm{~m}$ ) and finished at the end of 2005 .

The Tuscan-Emilian Apennine is a typical thrust-fold belt, where different tectonic units were thrusted over one another due to compressive strengths resulting from the collision between the African and Euro-Asiatic plates. Since the Messinian, tectonic movements from the Tuscan coastline to the Apenninic divide have become mainly vertical due to extensional tectonics related to the opening of the Tirrenian Sea (Bendkik et al. 1994; Boccaletti et al. 1997; Cerrina Feroni et al. 2002).

The Firenzuola tunnel is located at the border between the two different tectonic domains: the first domain (north of the main water divide) is mainly characterized by thrusts and low-inclination faults; the second domain (farther to the south) is characterized by normal faults related to the opening of the Mugello graben, where fluvio-lacustrine sediments accumulated during the Pleistocene (Bernini et al. 1990; Boccaletti et al. 1995a, 1995b, 1999).

The tunnel is mostly drilled through siliciclastic turbidite units of the Miocene Marnoso Arenacea Formation (FMA), which consists of arenitic layers (sandstones) and pelitic layers (marls) (Ricci Lucchi 1986; Zattin et al. 2000). The FMA can be subdivided into lithostratigraphic members according to the ratio of arenitic to pelitic layers ( $\mathrm{A} / \mathrm{P}$ ratio) (Cibin et al. 2004; Amy and Talling 2006). The tunnel crosses, from north to south, the following geological formations and FMA members (Fig. 2): the Bassana member (FMA7), A/P $\approx 1$, from the northern entrance to $\mathrm{km} \mathrm{48+000;} \mathrm{the} \mathrm{Nespoli}$ member (FMA8), A/P > 1, from $\mathrm{km} \mathrm{48+000} \mathrm{to} \mathrm{km} \mathrm{49+450}$ and from $\mathrm{km} \mathrm{49+800} \mathrm{to} \mathrm{km} \mathrm{50+300;} \mathrm{the} \mathrm{Argille} \mathrm{Varicolori}$ con Calcari (AVC), a mainly argillitic unit pertaining to the Unità Tettonica Sestola Vidiciatico (Bettelli and Panini 1991; Bettelli et al. 2002), from $\mathrm{km} 49+450$ to $\mathrm{km} \mathrm{49+800;} \mathrm{the}$ Collina member (FMA5), A/P $=1 / 5$ or $1 / 6$, from $\mathrm{km} 50+300$ to $\mathrm{km} \mathrm{50+450;} \mathrm{the} \mathrm{Galeata} \mathrm{member} \mathrm{(FMA4),} \mathrm{A} / \mathrm{P}=1 / 2$ to $1 / 3$, from $\mathrm{km} \mathrm{50+450} \mathrm{to} \mathrm{km} \mathrm{50+700;} \mathrm{and} \mathrm{the} \mathrm{Premilcuore}$ member (FMA3), A/P > 1, from km 50+700 to km 54+700.

From km 55+600, the Firenzuola tunnel crosses Tuscan units (Unità Toscane), thrusted over the FMA due to a regional inverse fault that is out of sequence (Bendkik et al. 1994; Cerrina Feroni et al. 2002; Cibin et al. 2004; Martelli et al. 2014). More specifically (Fig. 2), the Tuscan units are as follows: the sandy-silty member of the Torrente Carigiola Formation (TCG), which includes siliciclastic turbidites with $\mathrm{A} / \mathrm{P}<1$, from km 54+700 to $\mathrm{km} \mathrm{55+600;} \mathrm{the} \mathrm{sandy-silty}$ member of the Acquerino Formation (AQR), which comprises siliciclastic turbidites with $\mathrm{A} / \mathrm{P}>1$, from $\mathrm{km} \mathrm{55+600} \mathrm{to}$ $\mathrm{km} \mathrm{55+650} \mathrm{and} \mathrm{from} \mathrm{km} \mathrm{55+900} \mathrm{to} \mathrm{km} \mathrm{55+980;} \mathrm{the} \mathrm{Marne}$ Varicolori di Villore Formation (MVV), which contains marls, from $\mathrm{km} \mathrm{55+650}$ to $\mathrm{km} \mathrm{56+300;} \mathrm{and} \mathrm{the} \mathrm{tunnel} \mathrm{crosses} \mathrm{the}$ fluvio-lacustrine succession of the Mugello graben (Fig. 1), which is represented by alluvial and lacustrine sediments composed of pebbles, sands and clays from $\mathrm{km} \mathrm{56+300} \mathrm{to} \mathrm{the}$ southern entrance.

\section{Hydrogeology Impacts of the tunnel on groundwater and surface waters}

During excavation of the Firenzuola tunnel, 14 major water inrushes occurred between 1999 and 2003 into the main tunnel and the access windows. Peak inflows were within a range of 30 to more than $500 \mathrm{~L} / \mathrm{s}$. The total drainage during 


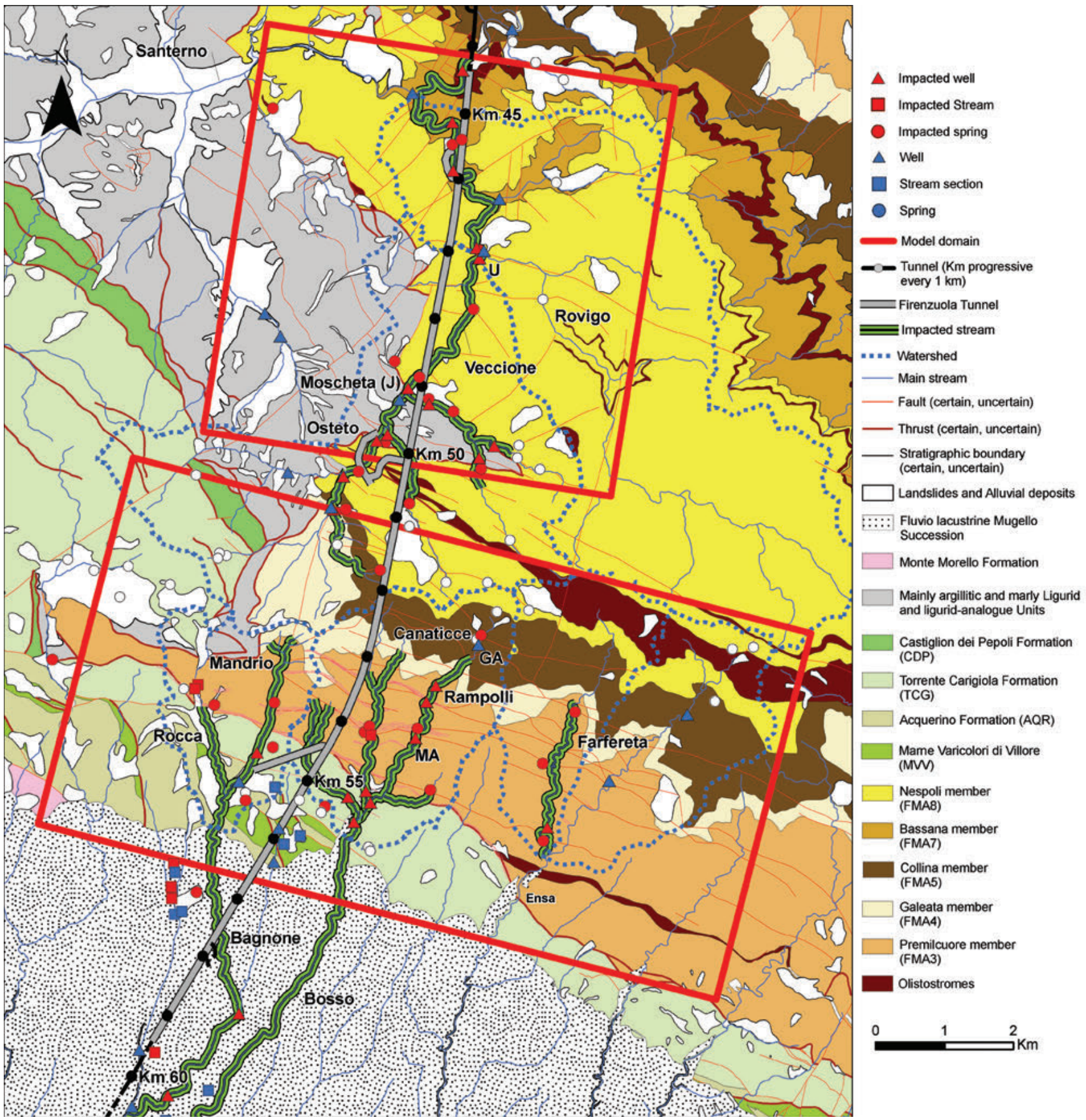

Fig. 1 - Geological and hydrogeological setting of the study area: main geological formations and distribution of impacts on the surface; with the red boxes, the two model domains are evident.

Fig. 1 - Inquadramento geologico e idrogeologico dell'area di studio: principali formazioni geologiche e distribuzione degli impatti idrogeologici in superficie; poligoni rossi individuano i due domini di modellazione.

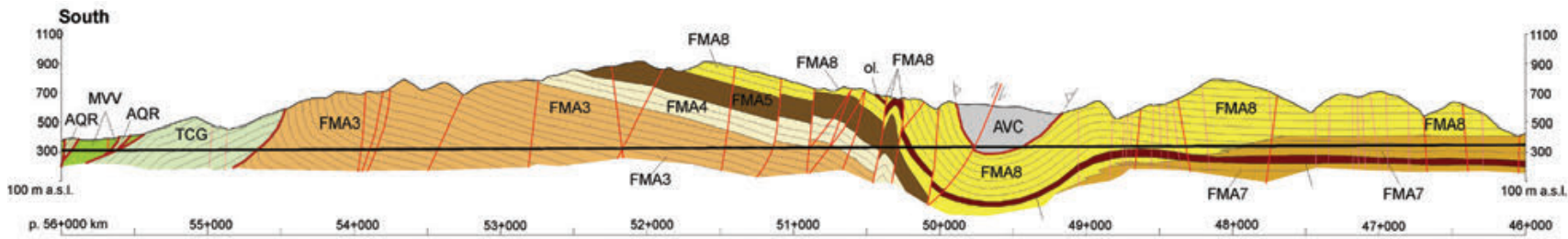

Fig. 2 - Geological section along the Firenzuola tunnel (modified from Vincenzi et al. 2009).

Fig. 2 - Sezione geologica lungo il tracciato della Galleria Firenzuola (modificato da Vincenzi et al. 2009). 
drilling advancement reached instantaneous flow rates of more than $1,000 \mathrm{~L} / \mathrm{s}$. Two years after completion of the Firenzuola tunnel, the average drainage outflow became 355 $\mathrm{L} / \mathrm{s}$ with an evident annual relationship: $210 \mathrm{~L} / \mathrm{s}$ at the end of the recession period in autumn but more than $400 \mathrm{~L} / \mathrm{s}$ during winter (Gargini et al. 2008).

The main impacts on springs and streams occur in zones consisting of turbidites with a high $\mathrm{A} / \mathrm{P}$ ratio: the Nespoli member on the northern side and the Premilcuore member on the southern side. As a consequence, 12 springs and 5 previously perennial streams (Rovigo and Veccione in the north; Bagnone, Bosso and Farfereta in the south) were completely or seasonally dried. The mechanisms of the impact were different in the north and in the south and were established by studying the space-time array of the inrushimpact relationships as derived by monitoring data collected by the hydrological monitoring program performed by the constructors during drilling advancement.

In the southern part (FMA3), the main inrushes occurred

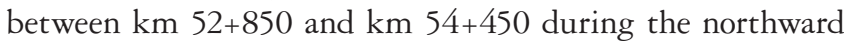
advancement of the Marzano window and the Firenzuola tunnel in 1999-2003 and are related to extensional fracture zones and faults parallel to the Mugello graben. All main springs aligned along these structures were completely dried, and the disappearance of summer flow in the five impacted streams was mainly related to water losses in the intersection zones between the streams and the extensional faults.

Analyzing the hydrological monitoring program data and integrating them through surveys done by the authors in 2000-2002 and 2005-2007, the progressive development of the impact has been inferred. Five main "impact events" can be identified from water inrushes during drilling advancement, including increasing drawdown observed in wells and decreasing spring and stream flows. Most of the impact events are related to tectonic extensional structures crossed by the tunnel, only two of which had been identified from the surface during geologic surveys before drilling (Vincenzi et al. 2009).

Hydraulic diffusivity was estimated by analyzing the time lags between tunnel inrushes and impacts on the surface, resulting in a mean value of approximately $1,000 \mathrm{~m} / \mathrm{month}$ (Gargini et al. 2008). Fast and intense impacts were also recorded on streams. However, the stream hydrographs consist of baseflow and direct flow, but the tunnel mainly reduces the baseflow, so the effects are evident mainly during recession periods.

Several watersheds were impacted by the tunnel on the southern side of the Apenninic chain. The most severe impacts can be observed in two tributaries of the Bosso Stream. During springtime, the western tributary (Canaticce) runs completely dry in its entire lower part, thereby exterminating all active aquatic organisms living in this previously permanent stream. The eastern tributary (Rampolli) also runs dry during summer in its lower part, although the springs in its upper part maintain their flow rates.

In the northern part (the Nespoli member), the main inrushes occurred between $\mathrm{km} \mathrm{45+900} \mathrm{and} \mathrm{km} \mathrm{48+200.} \mathrm{Due}$ to the absence of long and continuous extensional fracture zones, these inrushes can be explained as drainage from a decompressed and generally fractured rock mass extending down to a depth of $200 \mathrm{~m}$. For the same reason, drainage in the tunnel does not propagate for such long distances as it does in the southern part. Several springs on slopes and streams (e.g., the Rovigo and Veccione Streams) were impacted by the tunnel shortly after the water inrushes occurred.

On the northern side, the tunnel most severely impacts the Veccione Stream, as well as the lower reaches of the Rovigo Stream, which are directly located above the tunnel and where rock coverage is thin, so that the stream-tunnel connections are obvious.

The tunnel crosses the Veccione watershed over a length of $5.5 \mathrm{~km}$. In two places, the tunnel passes directly under the stream: at $\mathrm{km} \mathrm{49+000} \mathrm{(the} \mathrm{main} \mathrm{tunnel)} \mathrm{and} \mathrm{near} \mathrm{km}$ $50+000$ (an access window). The impacts are not restricted to these zones, but the stream flow surveys revealed significant seepage losses along most of the stream.

Moreover, the flow measurement data at the final sections of the catchments allowed the comparison of the mean baseflow of different streams before (1995-1998) and after (20052006) tunnel excavation, thus providing the baseflow loss estimate. Only stream discharge measurements taken at least 5 days after the last rain were considered for the calculation of the baseflow values.

The baseflow losses range from 40 to $84 \%$. The highest value corresponds to the Bosso Stream; dramatic losses (65\%) have also been observed in the Veccione Stream, a tributary of the Rovigo Stream.

The slight decrease in the total annual rainfall (8\% less rainfall in 2005-2006 compared to 1995-1998) is not sufficient to explain this substantial baseflow loss, which can mainly be attributed to drainage into the tunnel. The total baseflow loss is $254 \mathrm{~L} / \mathrm{s}$, which is less than the total outflow of the tunnel (355 L/s in 2005-2006), suggesting that the system is still in a transient state and that further impacts should be expected.

\section{Tracer tests}

The monitoring data that were collected and analyzed allow the identification of the impacted stream sections only in a general way. However, to locate the most important infiltration zones in the streambeds and to characterize their evolution over the years, repeated and detailed stream surveys and multitracer tests with fluorescent dyes were performed within the framework of this study. The results of this study, available in Vincenzi et al. (2009), are the main data source for the modelling study presented here and are briefly summarized.

Applying the salt dilution method (Käss 1998), flow measurement profiles were obtained and repeated during the spring-summer seasons, i.e., flow measurements were taken at different sections of the same stream, from downstream to upstream, to identify the losing stream reaches and to compare them with geological structures. 
As an example, along the Rampolli Stream, the two infiltration zones, where drying starts in early June, are related to two tectonic structures. In the following weeks, the dry part of the stream migrates progressively upstream due to additional infiltration zones. During summer, the stream remains dry until intense rainfall occurs, and recharge restarts in autumn or winter.

In June 2006, the discharge of the Veccione Stream decreased from 60 to $30 \mathrm{~L} / \mathrm{s}$ in the middle section of the stream (near $\mathrm{km} \mathrm{49+000)}$ ) and from 46 to $25 \mathrm{~L} / \mathrm{s}$ in the lower section of the stream (near $\mathrm{km} \mathrm{47+000)}$ within 11 days, demonstrating that the gaining stream had transformed into a losing stream. On 18 July 2006, the stream started to dry up in the lower section, and the dry part slowly propagated upstream. In September, the entire lower and middle section of the stream was dry until the beginning of December due to a particularly dry autumn.

In Vincenzi et al. (2009), two multitracer tests, each using uranine and sulforhodamine $G$, were carried out for the two impacted catchments (Veccione in the northern sector and Bosso in the southern sector) to confirm and quantify the stream-aquifer-tunnel interrelations. The results suggested the connection between losing streams and numerous water inlets in the tunnel, with maximum linear distances of 1.4 $\mathrm{km}$ and velocities reaching $135 \mathrm{~m} / \mathrm{d}$. The tracing experiments allowed the main stream-tunnel connections, i.e., geological structures responsible for the drainage of superficial waters by the Firenzuola tunnel, to be inferred. Several of the demonstrated flow paths passing under previous groundwater divides (mountain ridges) in the direction perpendicular to the tunnel proved that drainage has completely modified the regional flow system. Significant differences were observed between the northern and southern sectors of the area: the higher velocities and longer distances traveled by the tracers in the southern sector confirm the higher permeability of the turbidites in this zone and explain the larger tunnel interference radius.

\section{Conceptual model}

A conceptual model of groundwater circulation in turbidites was recently proposed on the basis of a large quantity of hydrogeological monitoring data related to tunnel excavations (Gargini et al. 2008; Vincenzi et al. 2009). According to this model, three main types of groundwater flow systems (GFSs) can be identified in turbidite aquifers:

- GFS1: This system is characterized by shallow groundwater circulation in the uppermost 100-200 $\mathrm{m}$, where stress release has caused intense fracturing; regolith, landslide deposits and debris also are present in this zone. A shallow GFS largely follows the topography and discharges into many small springs (often $<1 \mathrm{~L} /$ s; a 'slope' type spring, S) or streams.

- GFS2: Along major extensional structures (steep and relatively deep-reaching fracture zones), linear flow systems develop, sometimes across several surface watersheds. These flow systems discharge to a few relatively large springs (with a mean discharge ranging from $1 \mathrm{~L} / \mathrm{s}$ to $>10 \mathrm{~L} / \mathrm{s}$; a 'transwatershed' type spring, $\mathrm{T}$ ) or directly to streams.

- GFS3: Deep regional circulation systems develop between the central parts of the mountain chain, where high recharge occurs, and the lower-lying areas at their margins. These flow systems often discharge into alluvial sediments or contribute to the baseflow of larger rivers in deeply incised valleys. Discrete discharge points are rare.

In the natural state, before tunnel excavation, the fractured turbidite aquifer discharged towards small springs (along creeks) and mountain streams, feeding the baseflow. Now, the draining tunnel has completely modified the system equilibrium, lowering the water table below the level of the streams and causing inversion of the natural groundwatersurface water interactions: gaining streams have transformed into perched losing streams, and the zones where springs discharged are now the losing reaches, where tracers infiltrated towards the tunnel.

\section{Aim of the work}

Even if aquifer restoration is not possible, as long as the tunnel continues to drain the aquifer, the flow that disappears during summer has induced the Florence County Government to evaluate and plan several mitigation strategies to preserve at least a minimum stream flow downstream of the impacted reaches. The strategies consider artificial feeding of streams coupled with local streambed sealing or bypass conduits in zones of preferred infiltration. Therefore, fundamental parameters to know are the stream flow rate drained by the tunnel on the different reaches of streams and the flow rate necessary to maintain the flow continuity along the streams.

The only approach that can take into account all the involved system variables is numerical modelling. It is mainly necessary to reproduce both tunnel drainage and the interaction between superficial water and groundwater.

As the main Apenninic divide represents a hydrodynamic threshold that prevents the impacts from spreading from the northern sector to the southern sector, two separate modelling domains have been performed: the Veccione and Rovigo Streams in the northern sector and the Rampolli Stream in the southern sector (Fig. 1), which are the streams that have major impacts and available tracer results.

\section{Materials and methods}

The EPM approach consists of considering the rock matrix along with the fractures (the rock mass) and assigning them average hydrodynamic properties over a rock volume sufficiently wide to be considered statistically representative (representative elemental volume or REV) (Long et al. 1982; Kanit et al. 2003). Inside the REV, it is assumed that the fracture distribution is casual and uniform and that the fracture width does not allow turbulent flow. Geometric and hydrodynamic properties of distinct fractures are not required, small computational efforts are necessary and good 
results can be obtained working on wide modelling areas (Mun and Ucrhin 2004). Different examples are available in the literature concerning the use of the EPM approach for the simulation of both flow and transport in fractured aquifers, including karst aquifers in some cases (Pankow et al. 1986; Teutsch 1993; Gburek et al. 1999; Rayne et al. 2001; Paradis et al. 2007; Worthington 2009). Most authors agree that the EPM approach is particularly suited for flow systems at a regional scale (Scanlon et al. 2003). At a more detailed scale and with higher heterogeneities, the EPM approach can give erroneous results in terms of flow directions or mass balance (e.g., wide karst conduits).

Siliciclastic turbidites of the FMA represent a good test site for the EPM due to the absence of karst phenomena and to a relatively homogeneous fracture pattern related to the $\mathrm{A} / \mathrm{P}$ ratio, tectonic events and detensioning (Gargini et al. 2006).

The REV dimensions suitable to represent the FMA are derived from geomechanical surveys at the surface (during preliminary investigations) and at drilling faces during tunnel boring.

The applied code is MODFLOW 2000, which is developed by U.S. Geological Survey (Harbaugh et al. 2000), and is an updated version of the original MODFLOW (Mcdonald and Harbaugh 1988). It solves the flow equation in 3 dimensions in saturated media according to the finite difference method.

To simulate surface water-groundwater interactions, the Streamflow-Routing Package (STR1) (Prudic 1989) is used. This results from a change in the original river package formulation (Mcdonald and Harbaugh 1988): STR1 simulates the surface water flow inside streams by propagating a flow rate from cell to cell, contemporaneous with their interaction with groundwater and controlled by the head differences between the streams and the aquifer and by the permeability of the seepage medium, i.e., the riverbed.

The drain package (DRN) (Harbaugh et al. 2000) is used to simulate tunnel drainage; it removes groundwater from the corresponding cells as a function of head differences (between the aquifer and the tunnel elevation) and the permeability around the tunnel.

\section{Set up of models \\ Discretization}

A model domain of $6000 \times 6000 \mathrm{~m}$ was set up for the Veccione catchment, extending from the Osteto window south to the confluence between the Rovigo Stream and the Santerno River to the north (Fig. 1).

The domain is oriented parallel to the Firenzuola tunnel line, with an inclination of $9^{\circ}$ from the north. On the horizontal plane, it is subdivided into cells of $25 \times 25 \mathrm{~m}$, while along the vertical axis, 7 variable thickness layers are represented, starting from the topographic surface derived from the DEM LiDAR relief from the Florence County Government. The bottom of the model is an almost horizontal plane at an elevation of $240 \mathrm{~m}$ a.s.l., with a light gradient parallel to the tunnel slope. The total thickness of the model varies between 100 and 900 meters.
The model domain of Fosso Rampolli, in the southern sector, is a $1018 \times 5500 \mathrm{~m}$ wide rectangle that includes the catchments of the Bagnone, Bosso, Farfereta and Ensa Streams and extends from the main Apenninic divide to the north to fluvio-lacustrine formations of Mugello to the south. The shorter edge is oriented N-S, according to the mean regional flow direction. On the horizontal plane, the domain is divided into cells of variable dimensions from $25 \times 25 \mathrm{~m}$ along the tunnel to $200 \times 200 \mathrm{~m}$ towards the western and eastern sides. The topographic surface comes from the same LiDAR relief, while the model bottom is parallel to the tunnel plane, with elevations between 270 and $180 \mathrm{~m}$ a.s.l. from north to south. The total model thickness is between 100 and $900 \mathrm{~m}$ and is divided into 7 layers of variable thickness in relation to topographic relief.

\section{Parameters}

In the Veccione domain, three permeability zones have been distinguished as a function of lithology and fracture density (Fig. 3a and Tab. 1a). The first zone represents the normally fractured FMA rock mass; the second zone corresponds to those sectors of the FMA where the fracture density is higher, which are derived from the superposition of geological data, impact distribution and tracer test results (Vincenzi et al. 2009); and the third zone represents the argillitic low permeability rock masses pertaining to the Ligurid Units,
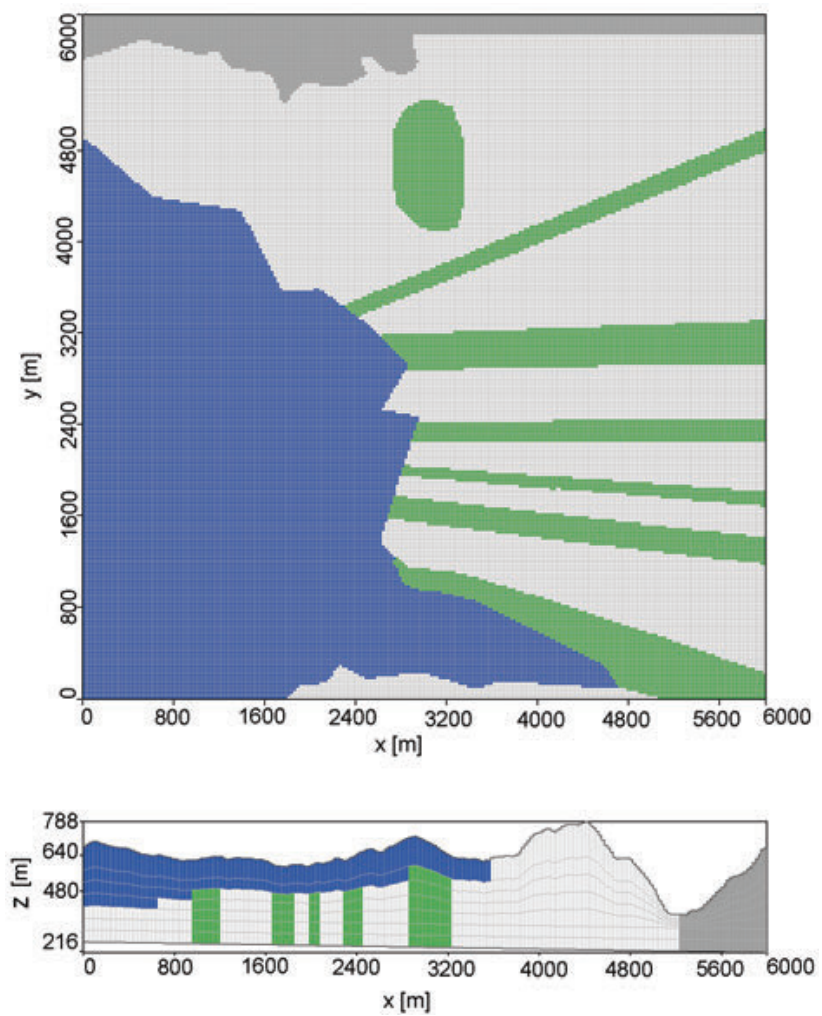

Fig. 3 a - Permeability zones of the Veccione model: plan view (above) and N-S section at $x=1750$ (below); the color legend is in Tab. 1a; the inactive cells are in gray.

Fig. 3 a - Zone di Conducibilità Idraulica del modello Veccione: vista planimetrica (in alto) e sezione N-S lungo la colonna $\mathrm{x}=1750$ (in basso); legenda colori in Tab. 1a; celle inattive in colore grigio. 
outcropping in the middle part of the Veccione catchment.

In the Fosso Rampolli domain, six permeability zones have been distinguished (Fig. 3b and Tab. 1b): normally fractured FMA turbidites; normal faults and high-density fracture zones inside FMA turbidites; argillitic units pertaining to the Ligurid Units; normally fractured siliciclastic turbidites of the TCG; and AQR turbidites and MVV marls.

Permeability is always assigned as an isotropic property, except for the normal faults/fracture zones, where an anisotropy factor of 10 is necessary along the $\mathrm{x}$ and $\mathrm{z}$ axes during the calibration process (Tab. 1b).

\section{Boundary conditions}

In the Veccione model, the regional gradient is represented by two $1^{\text {st }}$ type boundary conditions (b.c.) (constant head in MODFLOW) on the northern and southern sides of the domain. The northern head varies from 650 to $450 \mathrm{~m}$ a.s.l., depending on the simulated conditions. To the south, the assigned head corresponds to the Santerno riverbed elevation (359 - $378 \mathrm{~m}$ a.s.l.), representing the discharge point of the regional flow system. No flow b.c. (Neumann or $2^{\text {nd }}$ type b.c.; inactive flow or no specified boundary in MODFLOW) have been used for the southern portion of the domain (under the Santerno River) and for the western and eastern sectors.

Recharge to the aquifer is simulated as $2^{\text {nd }}$ type b.c. (recharge in MODFLOW) applied to all the cells of the $1^{\text {st }}$ layer, which distinguishes between turbidites (recharge value of $115 \mathrm{~mm} /$ year) and argillitic units (2 mm/year).

In the Fosso Rampolli model, $2^{\text {nd }}$ type b.c. are applied to the $1^{\text {st }}$ layer to simulate the recharge, and 3 zones are distinguished: FMA turbidites, with $200 \mathrm{~mm} /$ year; argillitic units with $2 \mathrm{~mm} /$ year; and TCG, AQR and MVV units with $100 \mathrm{~mm} /$ year.

Tab. 1 - Permeability values of the different zones: a) Veccione model (see Fig. 3a); b) Fosso Rampolli model (see Fig. 3b).

Tab.1 - Valori di Conducibilità Idraulica (K) assegnati alle diverse zone del dominio: a) modello Veccione (Fig. 3a); b) modello Fosso Rampolli (Fig. 3b)

\begin{tabular}{|c|c|c|c|c|}
\hline \multicolumn{5}{|c|}{ a) Veccione model } \\
\hline Zone & Hydrogeological Unit & $\mathrm{K}_{\mathrm{x}}(\mathrm{m} / \mathrm{s})$ & $\mathrm{K}_{\mathrm{y}}(\mathrm{m} / \mathrm{s})$ & $\mathrm{K}_{\mathrm{z}}(\mathrm{m} / \mathrm{s})$ \\
\hline 1 & Rock mass normally fractured (FMA), aquifer & $1.0 \mathrm{E}-07$ & $1.0 \mathrm{E}-07$ & $1.0 \mathrm{E}-07$ \\
\hline 2 & Ligurian argillitic units, aquiclude & $1.0 \mathrm{E}-09$ & $1.0 \mathrm{E}-09$ & $1.0 \mathrm{E}-09$ \\
\hline 3 & Rock mass with higher fracture density (FMA), aquifer & $5.0 \mathrm{E}-06$ & $5.0 \mathrm{E}-06$ & $5.0 \mathrm{E}-06$ \\
\hline \multicolumn{5}{|c|}{ b) Fosso Rampolli model } \\
\hline Zone & Hydrogeological Unit & $\mathrm{K}_{\mathrm{x}}(\mathrm{m} / \mathrm{s})$ & $\mathrm{K}_{\mathrm{y}}(\mathrm{m} / \mathrm{s})$ & $\mathrm{K}_{\mathrm{z}}(\mathrm{m} / \mathrm{s})$ \\
\hline 1 & Rock mass normally fractured (FMA), aquifer & $1.0 \mathrm{E}-07$ & $1.0 \mathrm{E}-07$ & $1.0 \mathrm{E}-07$ \\
\hline 2 & Ligurian argillitic units, aquiclude & $1.0 \mathrm{E}-09$ & $1.0 \mathrm{E}-09$ & $1.0 \mathrm{E}-09$ \\
\hline 3 & Rock mass with higher fracture density (FMA), aquifer & $1.0 \mathrm{E}-04$ & $1.0 \mathrm{E}-05$ & $1.0 \mathrm{E}-04$ \\
\hline 4 & Rock mass normally fractured (TCG), aquifer & $1.0 \mathrm{E}-07$ & $1.0 \mathrm{E}-07$ & $1.0 \mathrm{E}-07$ \\
\hline 5 & Rock mass normally fractured $(A Q R+M V V)$, aquitard & $8.0 \mathrm{E}-08$ & $8.0 \mathrm{E}-08$ & $8.0 \mathrm{E}-08$ \\
\hline
\end{tabular}
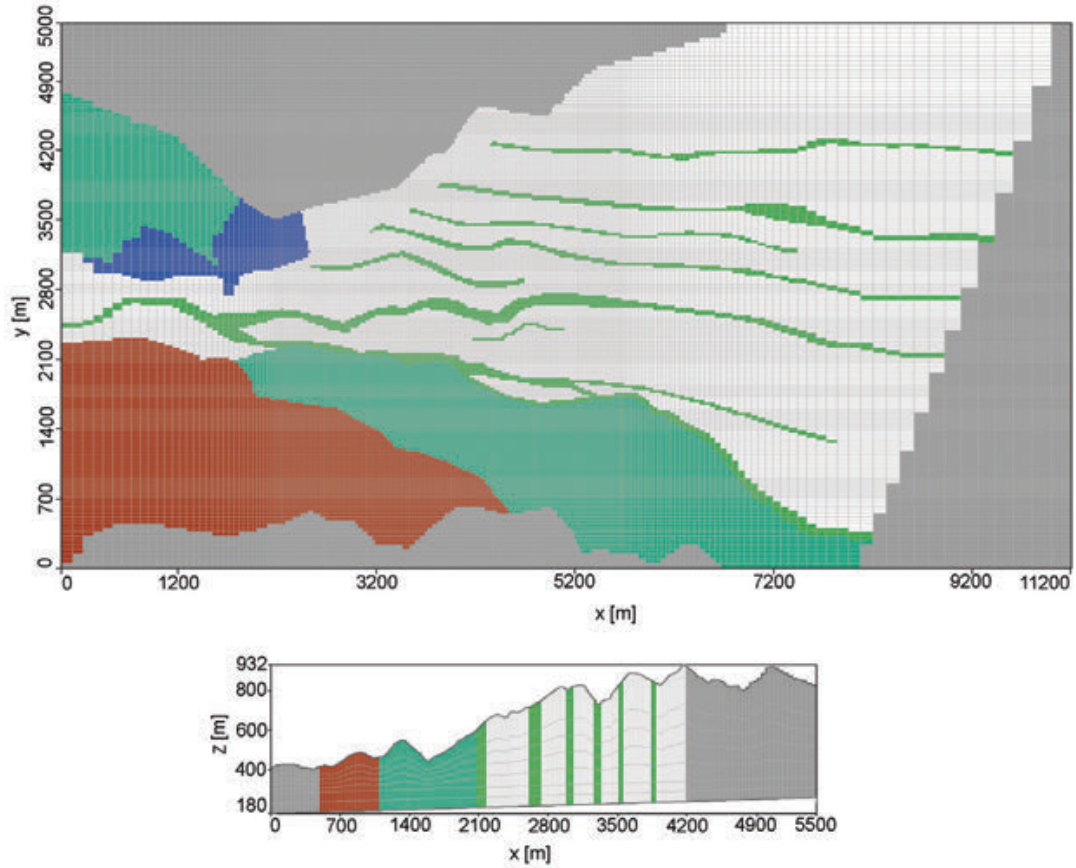

Fig. 36 - Permeability zones of the Fosso Rampolli model: plan view (above) and N-S section at $x=4000$ (below); the color legend is in Tab. 1b; the inactive cells are in gray.

Fig. 3b - Zone di Conducibilità Idraulica del modello Fosso Rampolli: vista planimetrica (in alto) e sezione N-S lungo la colonna $\mathrm{x}=4000$ (in basso); legenda colori in Tab. 1b; celle inattive in colore grigio. 
No flow b.c. are applied to the western and eastern boundaries of the domain and to all the cells on the other side of the main Apenninic divide. The regional groundwater flow and the feeding of fluvio-lacustrine sediments of the Mugello graben are simulated using a $3^{\text {rd }}$ b.c. type along the southern boundary through the DRN package of MODFLOW.

In both models, the tunnel is simulated by means of the DRN package; the elevation assigned to the drain is that of the tunnel, while the conductance values (parameters that represent the resistance opposed to flow by the rock mass all around the tunnel; Zaadnoordijk 2009) are derived from the calibration process and vary from 1 to $3 \mathrm{~m}^{2} /$ day.

The surface water-groundwater interaction is always simulated by means of a $3^{\text {rd }}$ type of b.c., the STR1 package of MODFLOW (Prudic 1989). It is assigned by dividing the streams into reaches and segments; every reach corresponds to one cell of the domain, while the segment is a group of connected cells along the surface flow direction. The stream flow rate is propagated from the value of the most upstream cell (starting point) and calculated for every cell downstream as the previous flow rate plus or minus the stream feeding or losing flow rate to the aquifer. The in/out flow is calculated by multiplying the head difference between the stream and the aquifer by the riverbed conductance. The stream level is calculated on every reach downstream to the first reach through Manning's equation for open channels (Ozbilgin and Dickerman 1984), while the conductance is derived from the riverbed dimensions (width and thickness) and permeability.

More specifically, the parameters used for the STR1 package are as follows: inflow to the first reach of the stream (derived from field measurements); riverbed thickness of $1 \mathrm{~m}$ (average value representative of this small mountain stream); river width from field measurements; roughness coefficient of Manning equal to 0.05 (Berti et al. 2003); and riverbed permeability taken as the same as the outcropping lithology.

Last, in the Fosso Rampolli model, two streams located towards the western boundary are represented with the River Package (RIV), which is the $3^{\text {rd }}$ type of b.c., due to the total absence of flow data and the impossibility of applying the STR1 package.

\section{Simulations}

In the steady-state calibration process of the Veccione model, two opposite hydrologic conditions are simulated: high flow and low flow of the aquifer system. In the first case, a field data set collected in December 2006, before the tracer test was performed, is used. Low-flow conditions simulate flow rates and dry sectors in streams as measured in September 2006. In both cases, the surface water flow rate measurements can be considered representative of the only baseflow contribution because they are made after periods without rainfall events. The value of the drainage from the corresponding sector of the Firenzuola tunnel is available for each field survey. Without head observation data, the calibration process is performed quantitatively on groundwater flow (tunnel drainage) and surface water flow, i.e., stream-aquifer exchange (Fig. 4 and Tab. 2).

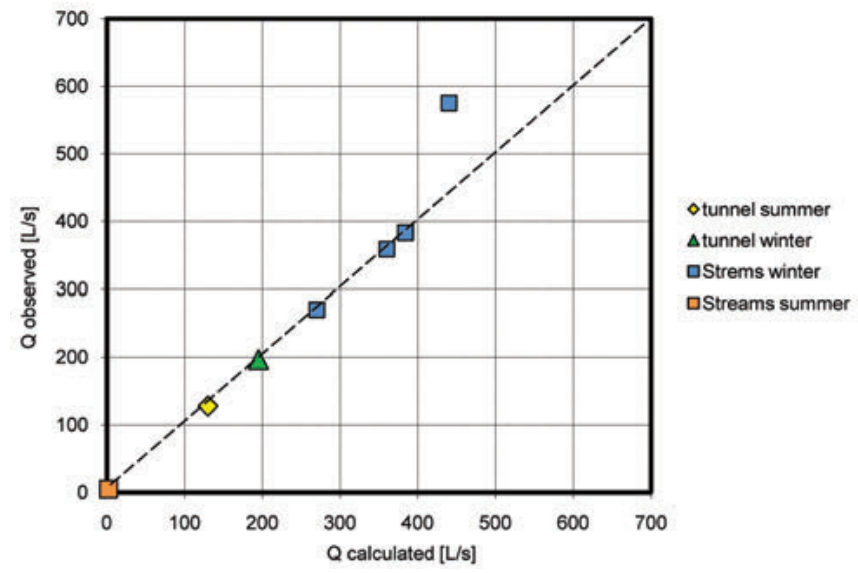

Fig. 4 - Calibration graph of the Veccione model: observed vs. calculated flow values.

Fig. 4 - Grafico di calibrazione del modello Veccione: portate osservate vs. calcolate.

Tab. 2 - Calibration statistical data of the Veccione model.

Tab. 2 - Dati statistici di calibrazione del modello Veccione.

\begin{tabular}{|l|l|}
\hline Residual Mean (L/s) & 22.40 \\
\hline Absolute Residual Mean (L/s) & 23.12 \\
\hline Root Mean Squared (L/s) & 4.81 \\
\hline Normalized Root Mean Squared (\%) & 1.09 \\
\hline
\end{tabular}

The Fosso Rampolli model is performed at steady state using hydrologic conditions measured in May 2006 during the tracing test. In addition to groundwater and surface water flow rates, piezometric levels measured at two impacted wells near the Firenzuola tunnel are available. The quantitative calibration reaches a good level (Fig. 5 and Tab. 3a) and is strengthened by the good comparison between the measured and the calculated head at the observation points (Tab.3b).

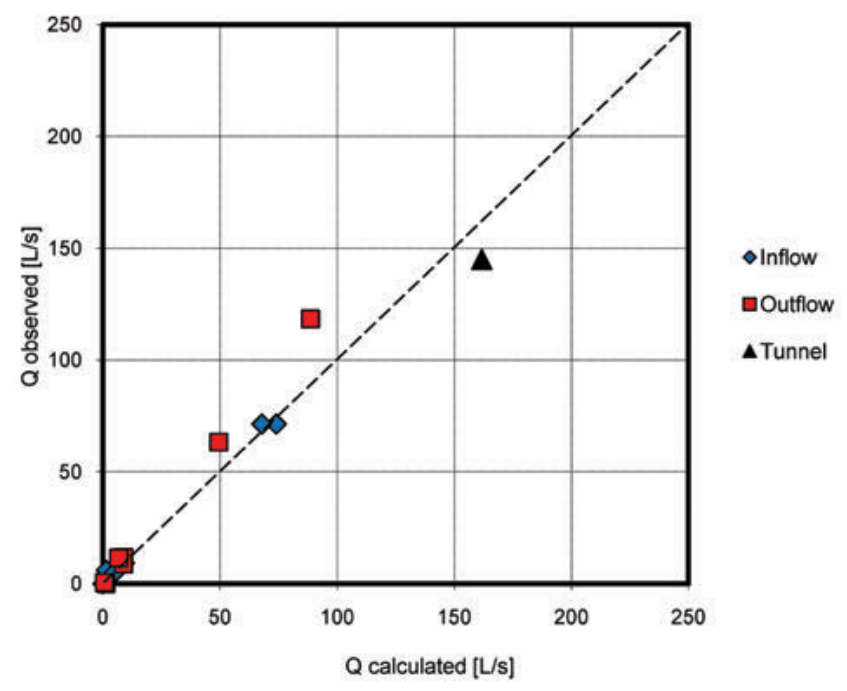

Fig. 5 - Calibration graph of the Fosso Rampolli model: observed vs. calculated flow values.

Fig. 5 - Grafico di calibrazione del modello Fosso Rampolli: portate osservate vs. calcolate. 
Tab. 3 - Calibration statistical data of the Fosso Rampolli model: a) flow rate data; b) head data.

Tab. 3 - Dati statistici di calibrazione del modello Fosso Rampolli: a) portate; b) carichi piezometrici.

\begin{tabular}{|l|c|c|c|}
\hline a) & Inflow & Outflow & Total Flow \\
\hline Residual Mean (L/s) & -0.75 & -3.33 & -2.18 \\
\hline Absolute Residual Mean (L/s) & 1.39 & 6.95 & 4.48 \\
\hline Root Mean Squared (L/s) & 2.24 & 11.82 & 8.94 \\
\hline Normalized Root Mean Squared (\%) & 3.09 & 6.57 & 7.55 \\
\hline
\end{tabular}

\begin{tabular}{|l|c|c|}
\hline b) & Erci Well & Incisa Well \\
\hline Observed Head (m a.s.l.) & 446 & 448 \\
\hline Calculated head (m a.s.l.) & 459 & 445 \\
\hline Residual Mean (m) & \multicolumn{2}{|c|}{4.60} \\
\hline Absolute Residual Mean (m) & \multicolumn{2}{|c|}{8.24} \\
\hline Root Mean Squared (m) & \multicolumn{2}{|c|}{9.44} \\
\hline
\end{tabular}

\section{Results}

Concerning the Veccione model, starting from the simulation calibrated at low flow conditions, different forecasting simulations are performed to assess the minimum artificial flow rate necessary for the upstream reach of the impacted stream (Ponte di Moscheta) to maintain flow continuity along the entire stream.

A flow rate derived from the average values of hydrological monitoring is assigned to the reaches not impacted by the tunnel: $2 \mathrm{~L} / \mathrm{s}$ for the Fosso dell'Isola Stream and $100 \mathrm{~L} / \mathrm{s}$ for the Rovigo Stream upstream of the confluence with the Veccione Stream (Fig. 1).

The minimum artificial flow rate needed at Ponte di Moscheta to maintain flow continuity along the Veccione Stream is between 30 and $40 \mathrm{~L} / \mathrm{s}$ (Fig. 6); above $40 \mathrm{~L} / \mathrm{s}$, the baseflow losses become stationary and are approximately 35 $\mathrm{L} / \mathrm{s}$ (Tab. 4). The artificial feeding of the Veccione Stream also helps the baseflow of the Rovigo Stream, whose losses stabilize at approximately $83 \mathrm{~L} / \mathrm{s}$ (Fig. 6 and Tab. 4).
A comparison with field measurements at the Moscheta section $(\mathrm{J})$ and at the confluence with the Rovigo Stream (U) allows validation of the results. The flow rate difference between the two sections represents the baseflow loss, which depends on the hydrologic conditions at the moment of the field measurement (Fig. 7). The maximum flow rate loss ever detected along the Veccione Stream is $66 \%$ of the total flow in the upstream section $(40 \mathrm{~L} / \mathrm{s})$, while the model calculates a value of $88 \%$.

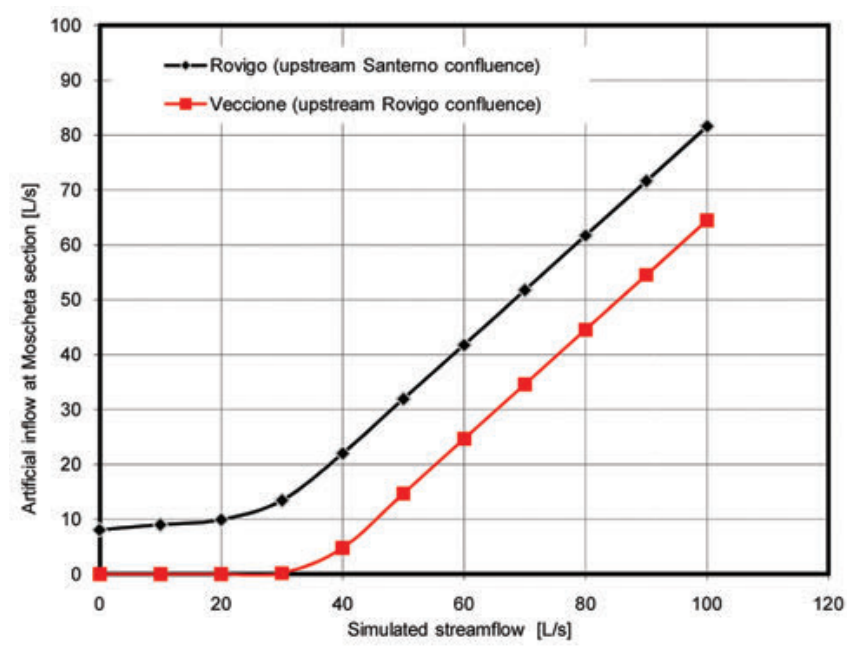

Fig. 6 - Results of the Veccione model: graphical comparison between the artificial inflow at the upstream section ( $y$ axis) and the residual flow rate at the downstream section of the impacted reach ( $x$ axis).

Fig. 6 - Risultati del modello Veccione: comparazione grafica tra portata artificiale alla sezione di monte (asse y) e portata residua alla sezione di valle del tratto d'alveo impattato (asse $\mathrm{x}$ ).

Tab. 4 - Results of the Veccione model: comparison between the artificial inflow at the upstream section and the residual flow rate at the downstream section of the impacted reach.

Tab. 4 - Risultati del modello Veccione: comparazione numerica tra portata artificiale alla sezione di monte e portata residua alla sezione di valle del tratto d'alveo impattato (asse x).

\begin{tabular}{|c|c|c|c|c|c|c|}
\hline \multirow{2}{*}{$\begin{array}{l}\text { Artificial inflow at } \\
\text { Moscheta (L/s) }\end{array}$} & \multirow{2}{*}{$\begin{array}{l}\text { Veccione outflow upstream } \\
\text { Rovigo confluence (L/s) }\end{array}$} & \multicolumn{2}{|c|}{ Loss } & Rovigo outflow upstream & \multicolumn{3}{|c|}{ Loss } \\
\cline { 3 - 8 } & $(\mathrm{L} / \mathrm{s})$ & $(\%)$ & Santerno confluence (L/s) & $(\mathrm{L} / \mathrm{s})$ & \multirow{2}{*}{$(\%)$} \\
\hline 0 & 0 & - & - & 8.07 & 91.93 & 85 \\
\hline 10 & 0 & 10.00 & 100 & 8.99 & 91.01 & 84 \\
\hline 20 & 0 & 10.00 & 100 & 9.91 & 90.09 & 82 \\
\hline 30 & 0.16 & 29.84 & 99 & 13.43 & 86.73 & 76 \\
\hline 40 & 4.77 & 35.23 & 88 & 21.99 & 82.78 & 68 \\
\hline 50 & 14.70 & 35.30 & 71 & 31.94 & 82.76 & 63 \\
\hline 60 & 24.65 & 35.35 & 59 & 41.78 & 82.87 & 58 \\
\hline 70 & 34.61 & 35.39 & 51 & 51.74 & 82.87 & 55 \\
\hline 80 & 44.56 & 35.44 & 44 & 61.69 & 82.87 & 51 \\
\hline 90 & 54.51 & 35.49 & 39 & 71.64 & 82.87 & 48 \\
\hline 100 & 64.47 & 35.53 & 36 & 81.6 & 82.87 & 46 \\
\hline
\end{tabular}




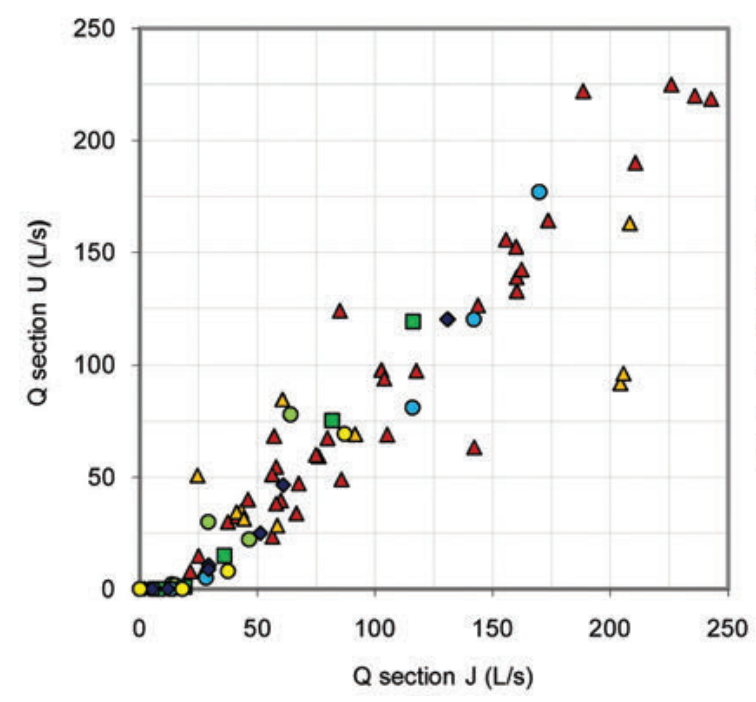

$\Delta 2001$

$\Delta 2002$

02003

$\square 2004$

02005

$\bullet 2006$

02007

Fig. 7 - Field flow measurements in 2001-2007: flow rates (Q) measured at the upstream section $(U)$ vs, the downstream section $(J)$ of the Veccione Stream.

Fig. 7 - Misure di portata sul campo anni 2001-2007: portate (Q) misurate alla sezione di monte (U) vs. portate misurate alla sezione di valle (J) del Torrente Veccione.

Forecasting simulations of the Fosso Rampolli model started from the unique calibrated simulation. The results show that a flow rate of $15 \mathrm{~L} / \mathrm{s}$ upstream of the impacted reaches is necessary to maintain flow continuity (Fig. 8). Baseflow loss became stable only above $30 \mathrm{~L} / \mathrm{s}$ (Tab. 5). Additionally, in this case, field measurements of environmental monitoring confirm model calculations: the comparison between the section upstream of the impacted reaches (GA) and the section downstream (MA) of the reaches shows that flow continuity is usually lost below $10 \mathrm{~L} / \mathrm{s}$ (Fig. 9).

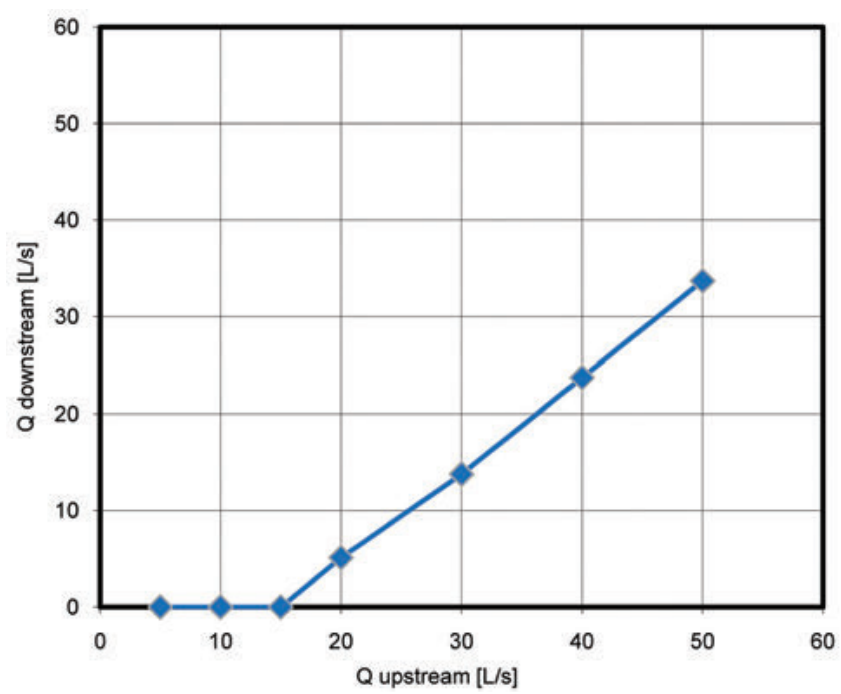

Fig. 8 - Results of the Fosso Rampolli model: graphical comparison between the artificial inflow at the upstream section ( $y$ axis) and the residual flow rate at the downstream section of the impacted reach ( $x$ axis).

Fig. 8 - Risultati del modello Fosso Rampolli: comparazione grafica tra portata artificiale alla sezione di monte (asse y) e portata residua alla sezione di valle del tratto d'alveo impattato (asse x).
Tab. 5 - Results of the Fosso Rampolli model: comparison between the artificial inflow at the upstream section and the residual flow rate at the downstream section of the impacted reach.

Tab. 5 - Risultati del modello Fosso Rampolli: comparazione numerica tra portata artificiale alla sezione di monte e portata residua alla sezione di valle del tratto d'alveo impattato.

\begin{tabular}{|c|c|c|c|}
\hline \multirow{2}{*}{$\begin{array}{c}\text { Q upstream } \\
(\mathrm{L} / \mathrm{s})\end{array}$} & Q downstream & \multicolumn{2}{|c|}{ Loss } \\
\cline { 3 - 4 }$(\mathrm{L} / \mathrm{s})$ & 0 & 5 & 100 \\
\hline 5 & 0 & 10.00 & 100 \\
\hline 10 & 0 & 15.00 & 100 \\
\hline 15 & 5.12 & 14.88 & 74 \\
\hline 20 & 13.77 & 16.23 & 54 \\
\hline 30 & 23.73 & 16.27 & 41 \\
\hline 40 & 33.68 & 16.32 & 33 \\
\hline 50 & & & \\
\hline
\end{tabular}

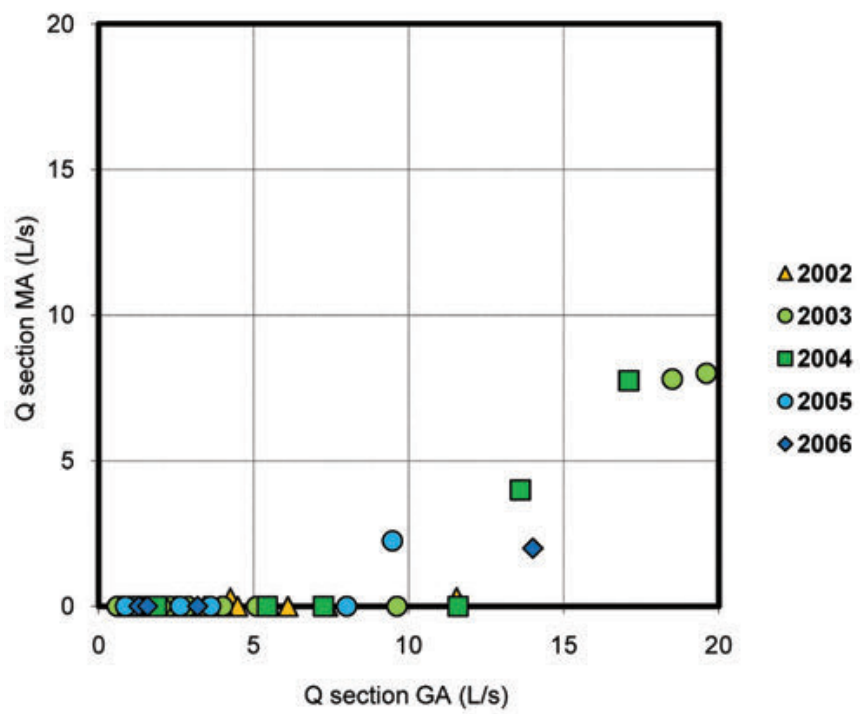

Fig. 9 - Field flow measurements in 2002-2006: flow rates (Q) measured at the upstream section (MA) vs, the downstream section (GA) of the Fosso Rampolli Stream.

Fig. 9 - Misure di portata sul campo anni 2002-2007: portate (Q) misurate alla sezione di monte (MA) vs. portate misurate alla sezione di valle (GA) del Torrente Fosso Rampolli.

\section{Discussion and conclusion}

The planning process of mitigation measures on the impacted streams requires a quantitative evaluation of streamtunnel flow rates in the three catchments with major impacts.

The evaluation is performed using numerical modelling with the EPM approach. The results provide evidence that this approach is capable of representing groundwater flow in fractured aquifers, not only at a regional scale but also at the catchment scale.

According to the modelling results, the Firenzuola tunnel at steady state drains at $35 \mathrm{~L} / \mathrm{s}, 83 \mathrm{~L} / \mathrm{s}$ and $30 \mathrm{~L} / \mathrm{s}$ to the baseflow of the Veccione, Rovigo and Fosso Rampolli Streams, respectively. If artificial water feeding is activated during the dry season, the minimum flow rates that are needed are 30 $\mathrm{L} / \mathrm{s}$ for the Veccione Stream and $15 \mathrm{~L} / \mathrm{s}$ for the Fosso Rampolli 
Stream. These flow rates were previously guaranteed by the upstream springs and particularly by the small springs aligned very close to the stream riverbeds.

The presented models are a further validation of the hydrogeological conceptual model because the congruence between the mass balance and the permeability distribution is verified.

Acknowledgment: Presented at Session "Hydrogeological impacts of tunnels", GEOITALIA 2009, Rimini, September 2009 (conveners: Alessandro Gargini, Valentina Vincenzi, Michele Sapigni).

\section{REFERENCES}

Agnelli A, Canuti P, Garavoglia S, Gargini A, Innocenti P (1999) Monitoraggio e vulnerabilità idrogeologica delle risorse idriche sotterranee lungo il tunnel ferroviario appenninico Alta Velocità Bologna-Firenze "Hydrogeological monitoring and vulnerability of groundwater resources along the underground High Velocity railway line between Bologna and Florence". Quaderni di Geologia Applicata, 2: 3329-3341.

Amy LA, Talling PJ (2006) Anatomy of turbidites and linked debrites based on long distance $(120 \times 30 \mathrm{~km})$ bed correlation, Marnoso Arenacea Formation, Northern Apennines, Italy. Sedimentology, 53: 161-212, doi:10.1111/j.1365-3091.2005.00756.x.

Bendkik AM, Boccaletti M, Bonini M, Poccianti C, Sani F (1994) Structural evolution of the outer Apennine chain (Firenzuola-Città di Castello sector and Montefeltro area, Tuscan-Romagnan and Umbro-Marchean Apennine). Mem. Soc. Geol. It., 48: 515-522.

Bernini M, Boccaletti M, Moratti G, Papani G, Sani F, Torelli L (1990) Episodi compressivi neogenico-quaternari nell'area estensionale tirrenica nord-orientale "Neogenic-quaternary compression episodes in the north-eastern Tyrrhenian extensional area. Data at sea and on land". Dati in mare e a terra. Mem. Soc. Geol. It., 45: 577-589.

Berti M, Elmi C, Muzzi E, Simoni A (2003) Interventi sulla morfologia. In: "Il recupero e la riqualificazione ambientale delle cave in Emilia", "Interventions on morphology" a cura di Muzzi E and Rossi G, Regione Emilia Romagna, Bologna.

Bettelli G, Panini F (1991) Liguridi, mélanges e tettoniti nel Complesso caotico lungo la "linea del Sillaro" (Appennino settentrionale, Province di Firenze e Bologna") "Ligurids, mélanges and tectonites in the chaotic complex along the "Sillaro line" (Northern Apennines, Provinces of Florence and Bologna)". Mem. Descr. Carta Geol. d'It., XLVI: 387415.

Bettelli G, Boccaletti M, Cibin U, Panini F, Poccianti C, Rosselli S (2002) Carta Geologica d'Italia a scala 1:50.000. Foglio 252 "Barberino di Mugello" "Geological Map of Italy, scale 1:50.000. Sheet 252 "Barberino di Mugello"”. Serv. Geol. d'It. - Regione EmiliaRomagna.

Boccaletti M, Bonini M, Moratti G, Sani F (1995a) Nuove ipotesi sulla genesi e l'evoluzione dei bacini post-nappe in relazione alle fasi compressive neogenico-quaternarie dell'Appennino Settentrionale "New hypotheses on the genesis and evolution of the post-nappe basins in relation to the compressive neogenic-quaternary phases of the Northern Apennines". Acc. Naz. Sci. detta dei XL, Scritti e Documenti, 14: 229-262.
Boccaletti M, Bonini M, Moratti G, Sani F (1995b) Le fasi compressive neogenico-quaternarie nell'Appennino settentrionale: relazioni con l'evoluzione dei bacini interni e con la tettonica del basamento "The Neogenic-Quaternary compression phases in the Northern Apennines: relations with the evolution of internal basins and the tectonics of basement". Studi Geol. Camerti, Vol. Spec., 1995/1: 51-72.

Boccaletti M, Gianelli G, Sani F (1997) Tectonic regime, granite emplacement and crustal structure in the inner zone of the Northern Apennines (Tuscany, Italy): a new hypothesis. Tectonophys, 270: 127-143, doi:10.1016/S0040-1951(96)00177-1.

Boccaletti M., Bonini M., Moratti G., and Sani F. (1999) - Compressive Neogene-Quaternary tectonics in the hinterland area of the Northern Apennines. Journ. Petrol. Geol., 22(1), 37-60, doi:10.1111/j.1747-5457.1999.tb00458.x.

Canuti P, Ermini L, Gargini A, Martelli L, Piccinini L, Vincenzi V (2009) Le gallerie TAV attraverso l'Appennino toscano: impatto idrogeologico ed opere di mitigazione "The TAV tunnels through the Tuscan Apennines: hydrogeological impact and mitigation works". EdifirEdizioni Firenze, Firenze, pp. 207.

Cerrina Feroni A, Martelli L, Martinelli P, Ottria G, con contributi di Catanzariti R (2002) Carta geologico-strutturale dell'Appennino emiliano-romagnolo in scala 1:250.000 "Geologic-structural map of the Apennines of Emilia-Romagna region, at scale 1:250,000". Regione Emilia-Romagna - CNR, Pisa. S.EL.CA., Florence.

Cibin U, Di Giulio A, Martelli L, Catanzariti R, Poccianti C, Rosselli $S$, Sani F (2004) Factors controlling foredeep turbidite deposition: the case of Northern Apennines (Oligo-Miocene, Italy). In: Lomas SA, Joseph P (eds) Confined turbidite systems. Geol. Soc. Lond. Spec. Publ., 222: 115-134, doi:10.1144/GSL.SP.2004.222.01.07.

Gargini A, Piccinini L, Martelli L, Rosselli S, Bencini A, Messina A, Canuti P (2006) Idrogeologia delle unità torbiditiche: un modello concettuale derivato dal rilevamento geologico dell'Appennino Tosco-Emiliano e dal monitoraggio ambientale per il tunnel alta velocità ferroviaria Firenze-Bologna "Hydrogeology of turbidite units: a model conceptual derived from the geological survey of the Tosco-Emiliano Apennines and environmental monitoring for the tunnels of FlorenceBologna high speed railway line". Bollettino della Società Geologica Italiana, 125: 293-327.

Gargini A, Vincenzi V, Piccinini L, Zuppi GM, Canuti P (2008) Groundwater flow systems in turbidites of the Northern Apennines (Italy): natural discharge and high speed railway tunnel drainage. Hydrogeology Journal, 16(8): 1577-1599, doi:10.1007/s10040-0080352-8.

Gburek WJ, Folmar GJ, Urban JB (1999) Field Data and Ground Water Modeling in a Layered Fractured Aquifer. Ground Water, 37(2): 175-184, doi:10.1111/j.1745-6584.1999.tb00972.x.

Harbaugh AW, Banta ER, Hill MC, Mcdonald G (2000) MODFLOW-2000, The U.S. Geological Survey modular groundwater model - User Guide to modularization concepts and the ground-water flow process. U.S. Geological Survey, Open-File Report 00-92, doi:10.3133/ofr200092.

Kanit T, Forest S, Galliet I, Mounoury V, Jeulin D (2003) Determination of the size of the representative volume element for random composites: statistical and numerical approach. International Journal of Solids and Structures, 40: 3647-3679, doi:10.1016/ S0020-7683(03)00143-4.

Käss W (1998) Tracing technique in geohydrology. Balkema, Rotterdam, pp. 600.

Long JCS, Remer JS, Wilson CR, Witherspoon PA (1982) Porous Media Equivalent for Networks of Discontinuous Fractures. Water Resources Research, 18(3): 645-658, doi:10.1029/ WR018i003p00645.

Lunardi P (1998) History of the Bologna to Florence rail connection. Gallerie e grandi opere in sotterraneo, 54: 16-21.

Lunardi P (2008) Design and construction of tunnels: analysis of controlled deformation in rocks and soils (ADECO-RS). Springer, 576 pp (partially available on Google books). 
Martelli L (2004) Mapping of foredeep turbidite successions: the Marnosoarenacea example from the Northern Apennines. In: Mapping Geology of Italy, Pasquarè G and Venturini C (eds). APAT, Dipartimento Difesa del Suolo, Servizio Geologico d'Italia, 207-212. S.EL.CA., Firenze.

Martelli L, Benini A, Poccianti C, Rosselli S (2014) Carta Geologica d'Italia a scala 1:50.000. Foglio 253 "Marradi" "- Geological Map of Italy, scale 1:50.000. Sheet 253 "Marradi”"'. APAT, Serv. Geol. d'It. Regione Emilia-Romagna.

Mcdonald MG, Harbaugh AW (1988) A Modular Three-Dimensional Finite-Difference Ground-Water Flow Model. U.S. Geological Survey, Techniques of Water-Resources Investigations, Book 6, Chapter A1, doi:10.3133/ofr83875.

Mun Y, Uchrin CG (2004) Development and Application of a MODFLOW Preprocessor Using Percolation Theory for Fractured Media. Journal of the American Water Resources Association, 40(1): 229-239, doi:10.1111/j.1752-1688.2004.tb01021.x.

Mutti E (1985) Turbidite systems and their relations to depositional sequences. In: Zuffa G.G. (Ed.), Provenances of Arenites, NATOAIS Series, D. Reidel Publishing Co.: 65-93, doi:10.1007/978-94017-2809-6_4.

Mutti E, Normark WR (1987) Comparing examples of modern and ancient turbidite systems: problems and concepts. In: Leggett JK and Zuffa GG (Eds.) Marine clastic sedimentology. Graham and Trotam, 1-38, London, doi:10.1007/978-94-009-3241-8_1.

Mutti E (1992) Turbidite sandstones. AGIP e Istituto di Geologia dell'Università di Parma.

Ozbilgin MM, Dickerman DC (1984) A Modification of the Finite Difference Model for Simulation of a Two-Dimensional GroundWater Flow to Include Surface-Ground Water Relationships. U.S. Geological Survey Water-Resources Investigations Report 83-4251, doi:10.3133/WRI834251.

Pankow JF, Johnson RL, Hewetson JP, Cherry JA, (1986) An evaluation of contaminant migration patterns at two waste disposal sites on fractured porous media in terms of the equivalent porous medium (EPM) model. J. Contaminant Hydrol., 1: 65-76, doi:10.1016/01697722(86)90007-0.

Paradis D, Martel R, Karanta G, Rene R, Michaud Y, Therrien R, Nastev M (2007) Comparative Study of Methods for WHPA Delineation. Ground Water, 45(2): 1585-167, doi:10.1111/j.17456584.2006.00271.x.

Prudic DE (1989) Documentation of a computer program to simulate stream-aquifer relations using a modular, finite-difference, groundwater flow model. U.S. Geological Survey, Open-File Report 88729, doi:10.3133/ofr88729.
Rayne TW, Bradbury KR, Muldoon MA (2001) Delineation of Capture Zones for Municipal Wells in Fractured Dolomite, Sturgen Bay, Wisconsin, USA. Hydrogeology Journal, 9: 432-450, doi:10.1007/ s100400100154

Ricci Lucchi F (1975) Miocene palaeogeography and basin analysis in the peri-Adriatic Apennines. Geology of Italy (Ed. by C.Squires), 2, 129-236, PESL-Tripoli.

Ricci Lucchi F (1978) Sedimentologia "Sedimentology", parte II C.L.U.E.B. Editore, pp. 210

Ricci Lucchi F (1980) Sedimentografia "Sedimentography" Zanichelli Editore, Bologna, pp. 290.

Ricci Lucchi F (1981) The Miocene Marnoso-Arenacea turbidites, Romagna and Umbria Apennines. Excursion $N^{\circ} 7$, Excursion Guidebook, $2^{\text {nd }}$ European Regional Meeting IAS.

Ricci Lucchi F (1986) The Oligocene to Recent foreland basins of the Northern Apennines. Int. Assoc. Sedimento. Spec. Publ., 8, 105 139, doi:10.1002/9781444303810.ch6.

Scanlon BR, Mace RE, Barrett ME, Smith B (2003) Can we simulate regional groundwater flow in a karst system using equivalent porous media models? Case study, Barton Springs Edwards aquifer, USA. Journal of Hydrology, 276: 137-158, doi:10.1016/S00221694(03)00064-7.

Teutsch G (1993) An extended double-porosity concept as a practical modelling approach for a karstified terrain. Hydrogeol. Processes in Karst Terranes, Proc. of the Antalya Symp. And Field Seminar, Oct. 1990, Intl. Assoc. Hyd. Sci. Publ., 207: 281-292.

Vallino Costassa G, Enrici Baion R, Pantaleo M (1997) L'Alta Velocità Ferroviaria tra Bologna e Firenze "The High Velocity Railway Line between Bologna and Florence". Quarry \& Construction, 3.

Vincenzi V, Gargini A, Goldscheider N (2009) Using tracer tests and hydrological observations to evaluate effects of tunnel drainage on groundwater and surface waters in the Northern Apennines (Italy). Hydrogeology Journal, 17(1): 135-150, doi:10.1007/s10040-0080371-5.

Worthington SRH (2009) Diagnostic hydrogeologic characteristics of a karst aquifer (Kentucky, USA). Hydrogeology Journal, 17: 16651678, doi:10.1007/s10040-009-0489-0.

Zaadnoordijk WJ (2009) Simulating Piecewise-Linear Surface Water and Ground Water Interactions with MODFLOW. Ground Water, 47(5): 723-726, doi:10.1111/j.1745-6584.2010.00740.x.

Zattin M, Landuzzi A, Picotti V, Zuffa GG (2000) Discriminating between tectonic and sedimentary burial in a fore deep succession, Northern Apennines. Journal of the Geological Society of London, 157: 629-633, doi:10.1144/jgs.157.3.629. 